\title{
MY BUSINESS AND I: ENTREPRENEUR PERSONALITY TRAITS AND CAPITAL STRUCTURE CHOICE
}

\author{
KELMARA M. VIEIRA ${ }^{1}$ \\ (iD) https://orcid.org/0000-0002-8847-0941 \\ VANESSA M. VALCANOVER ${ }^{2}$ \\ (iD) https://orcid.org/0000-0001-7576-0205 \\ ANI C. G. POTRICH \\ (iD) https://orcid.org/0000-0002-9444-5267 \\ EVERTON A. CAVALHEIRO ${ }^{3}$ \\ (D) https://orcid.org/0000-0002-6767-3889
}

To cite this paper: Vieira, K. M., Valcanover, V. M., Potrich, A. C. G., \& Cavalheiro, E. A. (2020). My business and I: Entrepreneur personality traits and capital structure choice. Revista de Administração Mackenzie, 21 (6), 1-33. doi:10.1590/1678-6971/eRAMD200300

Submission: Mar., 13, 2020. Acceptance: Jun., 9, 2020.

\footnotetext{
Federal University of Santa Maria (UFSM), Santa Maria, RS, Brazil.

2 Federal University of Santa Catarina (UFSC), Florianópolis, SC, Brazil.

3 Federal University of Pelotas (UFPEL), Pelotas, RS, Brazil.
}

\section{(cc) BY




\section{ABSTRACT}

Purpose: This research seeks to identify how entrepreneurs' personality traits can influence the capital structure of micro and small private businesses in Brazil, which are important for the economic growth and the subsistence of their owners.

Originality/value: The study of the behavioral dimension of business decisions can help financial agents to better understand client behavior, including the adoption of mechanisms that identify possible risky or inefficient decisions made by managers based on their personality traits. It can also assist the government and institutions supporting micro and small private businesses in developing strategies to reduce the mortality of such companies.

Design/methodology/approach: The proposed model involves 19 expected relationships that evaluate the relationships between the optimism, risk tolerance, sense of control (external and internal), attitude towards debt, and entrepreneur gender constructs. The sample includes 625 micro and small entrepreneurs in the state of Rio Grande do Sul, Brazil. Confirmatory factor analysis and structural equation modeling were performed.

Findings: Results showed that attitude towards debt and gender were the most significant constructs and had a direct influence on the capital structure, while optimism and internal locus of control exerted a negative indirect influence, while risk tolerance had a positive indirect effect. Female managers demonstrated higher optimism and internal locus of control than male managers, but they had a worse attitude towards debt.

\section{KEYWORDS}

Micro and small private businesses. Capital structure. Personality traits. Decision-making. Behavioral finances. 


\section{INTRODUCTION}

Capital structure is the combination of debt and equity that supports company assets (Tirole, 2006). In this context, micro and small private businesses differ from large companies because, due to personal financial guarantees and the legal framework, owners may not have the advantage of limited liability. These companies also tend to suffer in obtaining credit because of the existence of incomplete information for evaluation (Ang, 1992; Daskalakis, Jarvis \& Schizas, 2013). Besides these restrictions, small businesses are very important to society. According to Yilmazer and Schrank (2010), these firms have monetary significance and are the core of business innovation, which helps in the economic growth. The authors emphasize the importance of such businesses in the household, and business ownership can be a family investment that would replace other assets.

Evidence has shown that small businesses search for alternative sources to supply their capital needs. For example, Ullah and Taylor (2007) have shown that the most used capital sources were the savings of the owner, relatives and friends. Daskalakis et al. (2013) argued that micro and small companies tend to rely heavily on their own funds and, although they would like to use more debt than they currently do, they face limitations in accessing debt financing. Waleczek, Zehren and Flatten (2018) found that owners use more personal resources in the early stages of their ventures as a strategic choice.

Many financial theories have tried to explain how companies choose their funding sources and the proportions of use, as in Modigliani and Miller (1958), Jensen and Meckling (1976), and Myers and Majluf (1984), which consider that managers act rationally concerning the decision-making process in companies. The rationality paradigm, present in these theories, cannot totally explain the capital structure decisions in micro and small companies. As a consequence, new chains of investigation, based on nonfinancial aspects like the personality traits of the owner-manager, values, and other characteristics are used to better explain the capital structure of such business entities.

The theory of personality traits is one of the main approaches to the study of the human personality (Kassin, 2003) and focuses on the measurement of traits or characteristics that differ among individuals, can influence the decision-making process, and are relatively stable over time (Matthews, Deary, \& Whiteman, 2009). According to Gider and Hackbarth (2010), some examples of personality traits are optimism and propensity to debt, 
and evidence suggests that the study of managerial personality traits can explain the residual variation of other theoretical approaches.

Based on these issues, this paper analyzes the impact of managerial personality traits on the capital structure of micro and small businesses. The following traits were verified: optimism, risk tolerance, sense of control (external and internal), attitude towards debt, and issues related to the gender of entrepreneurs. A survey was applied to a sample of 625 micro and small entrepreneurs situated in the state of Rio Grande do Sul, which had a population of more than 1.2 million businesses in 2020, according to DataSebrae (2020).

Through the use of confirmatory factor analysis (CFA) and structural equation modeling (SEM), the results revealed that all the analyzed traits save the non-validated external locus of control, exerted some kind of influence on the capital structure. Attitude towards debt and gender had a direct influence, optimism and internal locus of control had a negative indirect influence, and risk tolerance had a positive indirect effect on capital structure. Besides that, female managers demonstrated higher optimism and greater internal locus of control than male managers, but showed a worse attitude towards debt.

\section{PERSONALITY TRAITS AND CAPITAL STRUCTURE: THEORETICAL MODEL}

Personality traits are organized mental structures that vary between individuals and guide individual behavior (Allport, 1937). They can be influenced by the environment and by the individual's own attributes (Hurley, 1998). Regarding the relationship of personality traits with capital structure, the first model to connect these concepts was developed by Heaton (2002), followed by Hackbarth (2008, 2009) and Gider and Hackbarth (2010).

Those models proposed that optimistic and overconfident managers believe that capital markets underestimate their companies' debt securities, and, therefore, they report a certain pattern of preference in front of funding sources. The theoretical model proposed in this research, thus, suggests that the personality traits considered (optimism, risk tolerance, sense of control, and attitude towards debt), together with gender issues, have a direct influence on personal indebtedness decisions and on the capital structure decisions of micro and small privately-held businesses. 
Optimism is a personality trait that shows some stability over time, produces a general state of strength and resilience, and is related to the long-term dimensions of an individual's life (Kluemper, Little, \& DeGroot, 2009). When linked to capital structure, optimistic entrepreneurs are more confident in the use of equity rather than debt, and a pessimistic entrepreneur would prefer debt instead of internal funding sources (Chaganti, De Carolis, \& Deeds, 1996). Hackbarth (2008, 2009), Gider and Hackbarth (2010), and Malmendier, Tate, and Yan (2011) also proposed that areater level of optimism causes a negative impact on the company's leverage, because owner-managers would prefer to use internal funding sources. Thus, the expected relationship is that a higher level of optimism has a negative impact on the capital structure of businesses (R1).

Risk tolerance is the limit to which an individual risks him/herself in a less favorable result, searching for a more favorable result (Roszkowski, Davey, \& Grable, 2005). According to Brealey and Myers (2003), when managers are less tolerant of risk, they tend to define the level of indebtedness considering their personal interests in sustaining a safe situation without financial difficulties for themselves and to the companies. Hutchinson (1995), Verheul and Thurik (2001), Barbosa and Moraes (2003), and Abdeldayem and Sedeek (2018) have shown that managers' risk tolerance is a determinant of the capital structure of the companies they manage, such that entrepreneurs more prone to risk tend to use more debt. It is, thus, expected that a higher level of risk tolerance has a positive impact on the capital structure of companies (R2).

Sense of control is understood as the individual's perception of his or her personal power over the control, the direction, and the goals of his or her life (Mendes-da-Silva \& Yu, 2009). Mirowsky (1995) observed that the sense of control has two loci: external and internal. Individuals with an external locus of control have a lower sense of control and tend to imagine that the occurrence of good results in their lives depends heavily on luck, and they feel like they have little control over their lives. Individuals with an internal locus of control tend to present a higher level of control, believe that they can get everything they want and are responsible for their own successes and failures.

Concerning the relationship between sense of control and capital structure, it has been argued that the greater the external locus of control, the greater the probability of the existence of personal debts (Livingstone \& Lunt, 1992; Tokunaga, 1993; Mewse, Lea, \& Wrapson, 2010). Thus, if the attitude towards debt is predictive of human behavior, according to Kraus 
(1995), it can be concluded that, all else being equal, an internal locus of control can influence debt aversion and, as a consequence, the capital structure of companies. Koropp, Kellermanns, Grichnik, and Stanley (2014) confirmed this premise, observing that sense of control was negatively linked to the disposition to use debt in the capital structure, leading to lower leverage. The following relationships are thus expected: first, a stronger internal locus of control has a negative impact on the capital structure of businesses (R3), while a stronger external locus of control has a positive impact (R4).

The fourth personality trait is attitude towards debt, a behavior presented by individuals regarding the incurrence of debts (Lea, Webley, \& Walker, 1995). Empirical evidence, as in Matthews, Vasudevan, Barton, and Apana (1994), Cronqvist, Makhija, and Yonker (2012), and Hoang and Otake (2014), has shown that the options of personal leverage are positively aligned with a company's leverage choices. Matthews et al. (1994) proposed theoretically that capital structure decisions are influenced by the owners' attitudes towards debt, such that owners more prone to debt tend to use a higher proportion of indebtedness in their companies' capital structure. These results are supported by the behavioral consistency theory, which proposes that individuals usually show consistent behaviors in different contexts (Cronqvist et al., 2012). Livingstone and Lunt (1992) and Stone and Maury (2006) have shown that the propensity to indebtedness is a strong predictor of debt. Thus, the expected relationship is that a more favorable attitude towards debt has a positive impact on capital structure (R5).

Regarding gender issues, Read (2002) has argued that obtaining funding was the main issue faced by women-led businesses. Many female entrepreneurs felt discriminated against by the financial institutions and faced resistance in their efforts to get credit for stereotyped reasons based on the institutions' lack of belief in their capacity to control a business. Research has also suggested that women tend to begin their businesses with a small amount of capital and are less inclined to raise capital from external sources (Constantinidis, Cornet, \& Asandei, 2006; Coleman \& Robb, 2009;).

When considering gender differences regarding debt in everyday life, Trindade, Righi, and Vieira (2012) affirmed that women have a rising responsibility for household expenses, which may increase their indebtedness. In many cases, women have lower earnings than men, making them more vulnerable to financial difficulties due to budget constraints (Levitan \& Wieler, 2008). Chaganti et al. (1996) and Carter, Brush, Greene, Gatewood and Hart (2003) have suggested that businesses led by women tend to present lower levels of bank indebtedness. Thus, one part of the literature suggests that 
female entrepreneurs tend to use more debt in their businesses, while another part suggests a tendency to use less debt in women-run businesses. This leads to the following expected relationship: gender affects the capital structure of businesses (R6).

It is important to approach the possible relationships and associations between the personality traits themselves. The relationship of optimism with attitude towards debt is observable, as a more optimistic manager is more prone to use equity than external funding (Chaganti et al., 1996). Risk tolerance is also related to optimism, such that it can help to explain optimism (Heaton, 2002), it is also directly related with attitude towards debt, in which a more risk-tolerant manager tends to use more debt, and a less risktolerant manager uses less debt (Ding, Chang, \& Liu, 2009). The expected relationships are that a higher level of optimism has a negative impact on the attitude towards debt (R7), while a higher level of risk tolerance has a positive impact on both optimism (R8) and attitude towards debt (R9).

Regarding sense of control, it has been verified that an internal locus of control is related to risk tolerance, affecting it negatively (Jacobs-Lawson, Waddell, \& Webb, 2011); it is positively related to optimism (Weinstein \& Klein, 1996); and negatively affects attitude towards debt (Koropp et al., 2014). Meanwhile, an external locus of control is negatively related to risk tolerance (Tokunaga, 1993); positively related to propensity to debt (Livingstone \& Lunt, 1992; Ding et al., 2009); and directly correlated with propensity to debt (Davies \& Lea, 1995). The following relationships are thus expected: first, a stronger internal locus of control has a negative impact on risk tolerance (R10), a positive one on optimism (R11), and negative on attitude towards debt (R12); second, a stronger external locus of has a negative impact on risk tolerance (R13) and a positive impact on attitude towards debt (R14).

Gender is related to the personality traits presented. For example, women tend to be more risk-averse and less prone to debt than men (Verheul \& Thurik, 2001; Constantinidis et al., 2006; Faccio, Marchica, \& Mura, 2016). However, authors like Levitan and Wieler (2008) and Trindade et al. (2012) have suggested that women can be more prone to acquiring debt than men if they face more financial difficulties than men. Sherman, Higgs, and Williams (1997) argued that men and women demonstrate similar behavior regarding the sense of control, but women tend to show a more prominent external locus of control in most of the measures used, and genders are affected differently by an internal locus of control for distinct aspects of life. Finally, regarding optimism, Jacobsen, Lee, Marquering, and Zhang (2014) found that men are more optimistic than women, while Hinz et al. (2017) obtained the opposite result. It is thus expected that female managers 
are less risk-tolerant than male managers (R15), and that gender affects both attitude towards debt (R16) and optimism (R17). Finally, it is also expected that female managers have both higher external (R18) and internal (R19) loci of control than male managers.

In Figure 2.1, the variables and constructs used and the expected relations are illustrated. Circles represent constructs, squares represent variables, and arrows indicate the expected influences.

\section{(Figure 2.1)}

\section{SCHEME OF THE VARIABLES USED AND THE EXPECTED RELATIONSHIPS}

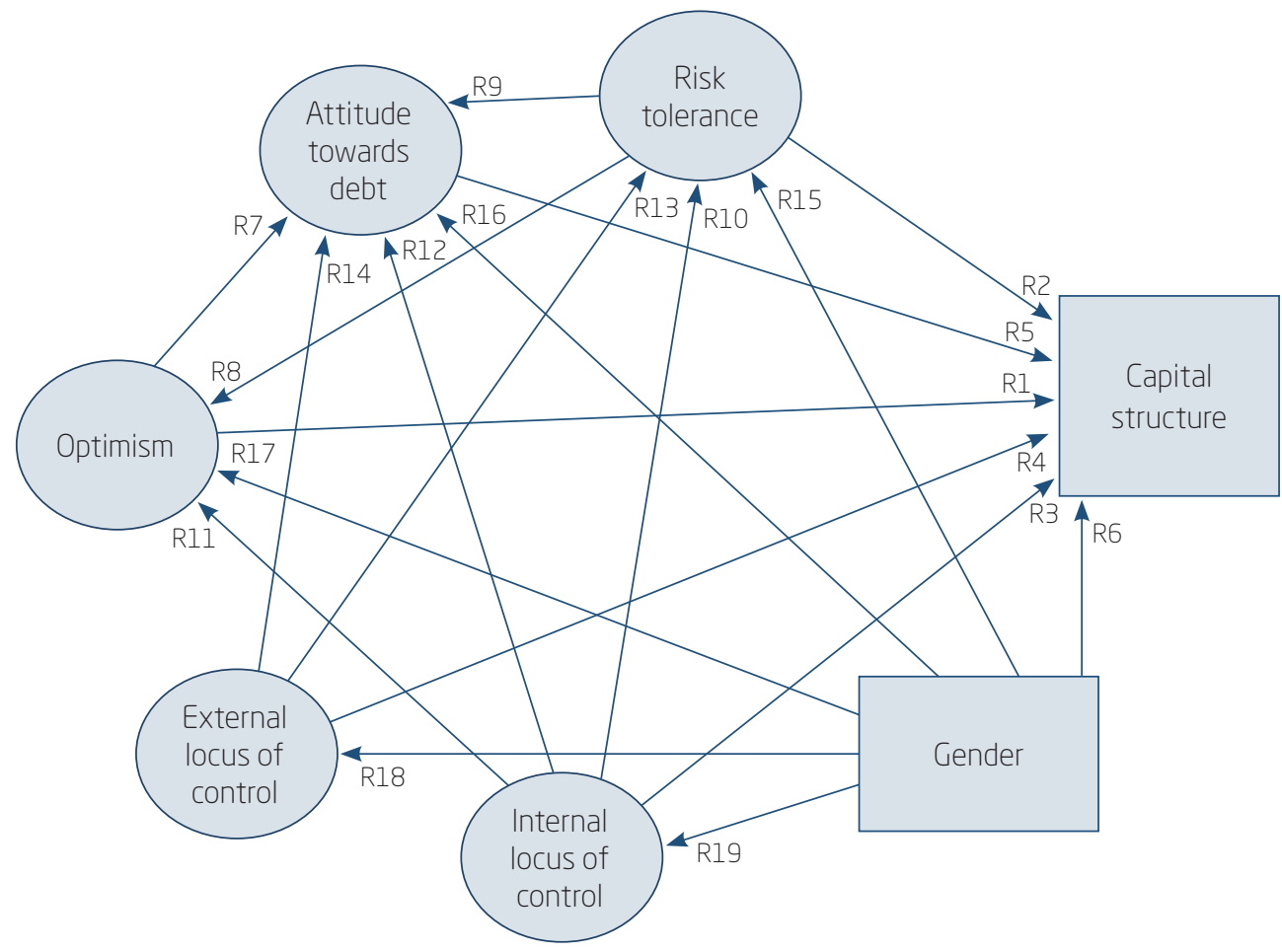

Note: Made using Amos ${ }^{\mathrm{Tm}}$.

Source: Elaborated by the authors.

\section{RESEARCH METHOD}

The research scenario considered Brazilian micro and small private businesses, which have an important role in the country's economic situation because they are the greatest proportion (almost $99 \%$ of businesses), the 
greatest employers (60\% of jobs), and represent an important slice of the country's gross domestic product (20\%) (Instituto Brasileiro de Geografia e Estatística, 2012). Businesses located in the state of Rio Grande do Sul, in the southern region of Brazil, were approached, a state with a population of 1,274,143 businesses (DataSebrae, 2020). In relation to the size of those businesses, $596,513(46.81 \%)$ were classified as individual micro-entrepreneurs; 516,631 (40.55\%) were micro-entrepreneurs; and 160,999 $(12.64 \%)$ were classified as other sizes. Regarding the economic sector, 543,175 (42.63\%) of those businesses were from the service sector; 451,517 (35.44\%) from the commerce sector; 152,555 (11.97\%) from industry; 117,191 (9.20\%) from civil construction; and 7,702 (0.60\%) from the agricultural sector, while 2,003 businesses $(0.16 \%)$ did not indicate their sector (DataSebrae, 2020).

Using a level of confidence of $95 \%$ and a sample error of $4 \%$, the sample was defined following the model by Malhotra (2011), reaching a final sample of 601 micro and small entrepreneurs. Due to the possibility of unfinished instruments, it was predicted that the application of 625 instruments would guarantee the sample's totality. Questionnaires were distributed randomly in the external environment through contact with micro and small entrepreneurs that agreed to participate.

A self-administered questionnaire was used as the instrument (see "Appendix"); the questionnaire was composed of 45 questions, divided into six groups. The first group of questions approached the manager's demographic profile, including gender, age, marital status, and education level. The following four groups involved Likert scales regarding risk tolerance (Droms \& Strauss, 2003), optimism (Scheier, Carver, \& Bridges, 1994), sense of control (Mirowsky \& Ross, 1991), and attitude towards debt (Moura, 2005). Finally, the sixth group measured company characteristics, such as age, profitability, sector, and capital structure, with questions regarding the indebtedness level, proposed by Yousuf (1997), who suggested that capital structure should be measured as the ratio between the values from questions 42 (debt) and 41 (assets) from the questionnaire.

Regarding data analysis, CFA and SEM were performed using the software SPSS $20.0{ }^{\circledR}$ and Amos $^{\mathrm{TM}}$. CFA was used to validate the constructs through the examination of convergent validity, unidimensionality, and reliability (Hair, Black, Babin, \& Anderson, 2010). The convergent validity of each construct was studied according to the magnitude and statistical significance of their standardized coefficients, as well as the absolute adjustment indices: chi-square $\left(\chi^{2}\right)$, root mean square residual (RMSR), root mean square error of approximation (RMSEA), goodness-of-fit index (GFI), and 
the comparative adjustment indices: comparative fit index (CFI), normed fit index (NFI), and Tucker-Lewis index (TLI). The literature does not agree regarding the acceptable values for each index. However, for the chi-square index/degrees of freedom, desirable values are below five; for CFI, GFI, NFI, and TLI, values above 0.90 are recommended; and for RMSR and RMSEA, values below 0.08 are desirable (Hair et al., 2010).

To evaluate if the factor coefficients or loads were significant, it was analyzed the significance and the magnitude of the factorial loads, such that variables with low loads were excluded from the model. To assess construct reliability, Cronbach's alpha and composite reliability were used, with acceptable values being above 0.6 for exploratory research (Hair et al., 2010). To measure unidimensionality, analysis of the standardized residuals was performed.

Finally, SEM was used to build and evaluate the integrated model and to verify the statistical significance of the estimated coefficients of regression to estimate the hypothesized theoretical structure and the adjustment indexes of the model. Aiming to bring robustness to the analysis, bootstrapping estimation was used to verify the stability of the parameters' estimates and to report their values with a higher level of accuracy (Byrne, 2013).

\section{ANALYSIS AND DISCUSSION OF RESULTS}

In the sample, $62.3 \%$ of the managers interviewed were male, $51.6 \%$ were married, $59.3 \%$ had attended high school, and the average age was 42.5 years. Regarding the businesses, their average age was 11 years, $60.8 \%$ were from the retail sector, $81.1 \%$ of the managers reported that they were not used to facing obstacles when trying to raise external funds for their businesses, and $49.5 \%$ said that the company had a good relationship with banks. Most of the sample (53.85\% of the managers) affirmed that their businesses were family businesses. However, $48.90 \%$ answered that there were no family members working at the business, $21.06 \%$ said that there were two family members, while $13.19 \%$ stated that there were three family members working on the business. It can thus be inferred that $51.1 \%$ of the firms had at least one family member of the manager working in them.

Regarding business assets, the results varied between BRL 10,000.00 and BRL 5,000,000.00 and the total average of assets was BRL 215,705,00, with a high standard deviation of BRL $444,154.00$. However, $53.85 \%$ of the businesses had total assets reaching up to BRL120,000.00, showing that more than half of the businesses in the sample were below the total average for assets. The total volume of debt fluctuated between less than BRL 
5,000.00 up to BRL 1,176,686.00, with an average of BRL 35,918.84 and standard deviation of BRL $82,537.00$. Moreover, $76.37 \%$ of the sample had up to BRL30,000.00 in debt, which is close to the total average debt. Capital structure varied from $0.50 \%$ to $342.85 \%$, showing a standard deviation of $34.17 \%$, and the average capital structure was $25.23 \%$ - that is, the debt compromised $25.23 \%$ of the companies' assets.

Next, the descriptive statistics of the personality traits are shown. Regarding optimism, managers appeared to be optimistic in general. For example, $53.5 \%$ agreed, and $23.6 \%$ totally agreed with the proposition "In uncertain times, I usually expect the best", while only $6.6 \%$ agreed, and $1.5 \%$ totally agreed with "If something can go wrong for me, it will". Concerning the sentence "Overall, I expect more good things to happen than bad", $46.7 \%$ of the respondents agreed, and $38.5 \%$ totally agreed.

Concerning sense of control, the results showed that an internal locus of control was prominent in the sample. For instance, $51.6 \%$ agreed, and $32.8 \%$ totally agreed with the proposition "I am responsible for my own success"; $53.5 \%$ agreed, and $24.9 \%$ totally agreed with "I am responsible for my failures"; and $48.4 \%$ disagreed with the statement "I have little control over the bad things that happen to me".

Concerning attitude towards debt, managers appeared to have a good relationship with their own resources, such that they were not prone to debt and, at the same time, not totally averse to it. $35.3 \%$ of the participants disagreed, and $28.6 \%$ totally disagreed with the statement "I think it's normal for people to be indebted to pay for things", while $40.3 \%$ agreed and $33.5 \%$ totally agreed with "It's not right to spend more than the amount I earn". However, $41.9 \%$ agreed with the sentence "Having debt is not a problem if I know I can afford it".

Regarding risk tolerance, managers seemed to be indifferent to risk, and the most chosen alternative was "neutral". For the sentence "Earning a high long-term total return that will allow my capital to grow faster than the inflation rate is one of my most important investment objectives", $40.8 \%$ of the respondents were neutral, while $37.5 \%$ agreed with it. Meanwhile, $43.4 \%$ of the entrepreneurs were neutral, and $26 \%$ agreed with the statement "I am willing to tolerate sharp up and downswings in the return on my investments to seek a potentially higher return than would normally be expected from more stable investments". To the proposition "I am financially able to accept a low level of liquidity in my investment portfolio", $41.2 \%$ of the managers were neutral, and $31.5 \%$ disagreed.

Validation of the constructs was performed through CFA. The measurement model of the constructs was thus adjusted, as shown in Figure 4.1. 


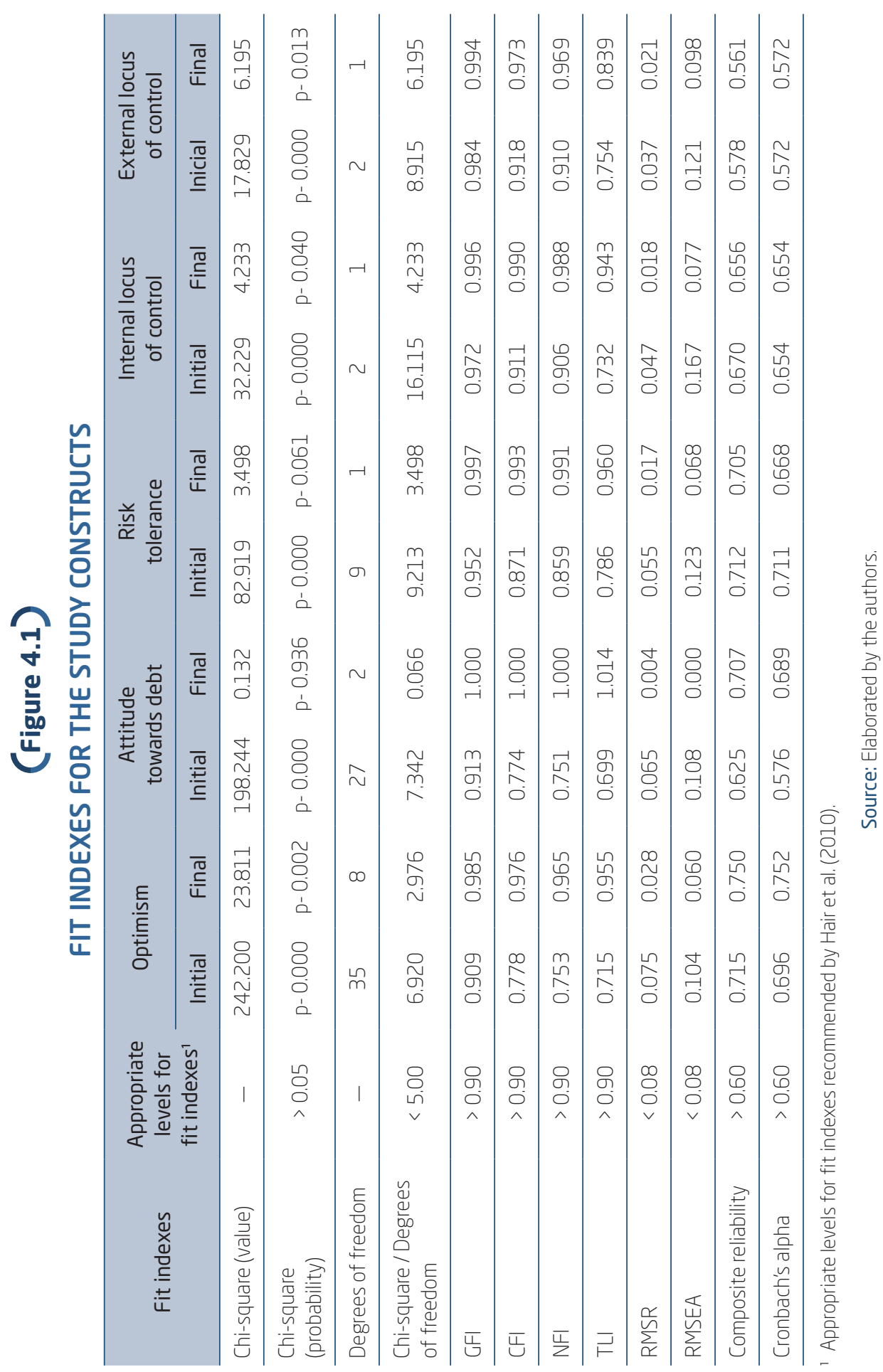


For the five constructs, the proposed models contained all of the variables presented in the original scale. However, the results indicated that all models were inadequate, because the chi-square/degrees of freedom were greater than five, and some fit indexes did not reach the minimum values. Searching for adequate models, variables with non-significant or low coefficients were removed, and correlations between variables' errors were inserted, both of them were suggested by the software and made theoretical sense.

Later, four models (optimism, attitude towards debt, risk tolerance, and internal locus of control) presented adequate adjustment: convergent validity, because CFI, GFI, NFI and TLI indexes were higher than 0.90 and RMSR and RMSEA indexes were below 0.08; reliability, given that the reliabilities were higher than 0.6 ; and unidimensionality, as evidenced by all standardized residuals falling below 2.58. The construct external locus of control was not validated, because the TLI and RMSEA indexes presented inadequate values, while the reliability was below 0.6 .

In the final model, from ten variables initially established for optimism, six were maintained (Q11, Q13, Q14, Q17, Q19, and Q20), and the ones with the greatest impact on this construct concerned whether the individuals expected good things to happen (Q19: coefficient 0.722) and that things would succeed for them (Q17: coefficient 0.676$)$. The final model for attitude towards debt consisted of four (Q29, Q32, Q33, and Q34) of the nine variables initially proposed. The fact of preferring to pay installments, even if it is more expensive (Q34: coefficient 0.830 ) and preferring to pay installments rather than expecting to have the cash to buy (Q33: coefficient 0.683 ) were the variables with the greatest impact on attitude towards debt.

The final model for risk tolerance was built with four (Q5, Q8, Q9, and Q10) of the six proposed variables, and those who could tolerate abrupt changes in return on their investments to achieve a potentially higher return than would normally be expected from more stable investments (Q8: coefficient 0.788 ) and those who would risk a loss in short-term return by a possibility of a higher rate of return in the future (Q9: coefficient 0.715 ) were more prone to be tolerant of risk. Concerning internal locus of control, the four proposed variables were integrated into the final model (Q21, Q22, Q23, and Q24), and only one correlation was included between the errors of questions 21 and 22. Individuals who agreed to be responsible for their failures (Q23: coefficient 0.907) and those who agreed that their failures resulted from the mistakes they made (Q24: coefficient 0.548$)$ were those with the highest internal locus of control.

Finally, based on the four validated personality trait constructs, with the inclusion of gender and capital structure, the integrated model was developed 
with 19 expected relations, which joins the measurement models and the structural model. The integrated model was assessed based on the fit indexes and the statistical significance of the estimated coefficients of regression, as shown in Figure 4.2.

\section{(Figure 4.2)}

FIT INDEXES FOR THE INTEGRATED MODEL

\begin{tabular}{lccc}
\hline \multirow{2}{*}{ Fit indexes } & $\begin{array}{c}\text { Appropriate levels } \\
\text { for fit indices }\end{array}$ & \multicolumn{2}{c}{ Integrated Model } \\
\cline { 3 - 4 } & $>0.05$ & Initial & Final \\
\hline Chi-square (probability) & $>0.90$ & 0.995 & 0.992 \\
\hline GFI & $>0.90$ & 0.961 & 0.966 \\
\hline CFI & $>0.90$ & 0.959 & 0.932 \\
\hline NFI & $>0.90$ & 0.410 & 0.926 \\
\hline TLI & $<0.08$ & 0.012 & 0.012 \\
\hline RMSR & $<0.08$ & 0.113 & 0.040 \\
\hline RMSEA & & & \\
\hline
\end{tabular}

Appropriate levels for fit indexes recommended by Hair et al. (2010).

\section{Source: Elaborated by the authors}

The model initially proposed presented some inadequate fit indexes and the chi-square was significant at $5 \%$, indicating no adjustment; the nonsignificant relationships were then disregarded. The final model presented adequate adjustment, after excluding seven relationships: R1, optimism impacts on the capital structure $(\mathrm{p}=0.483)$; $\mathrm{R} 2$, risk tolerance impacts on the capital structure ( $\mathrm{p}=0.251)$; $\mathrm{R}$, internal locus of control impacts on the capital structure $(\mathrm{p}=0.398) ; \mathrm{R} 8$, risk tolerance impacts on the optimism $(\mathrm{p}=$ $0.071)$; R10, internal locus of control impacts on the risk tolerance $(\mathrm{p}=0.245)$; $\mathrm{R} 15$, gender impacts on the risk tolerance $(\mathrm{p}=0.078)$; and $\mathrm{R} 16$, gender impacts on the attitude towards debt $(\mathrm{p}=0.189)$.

The expected relationships R4 (external locus of control impacts on the capital structure), R13 (external locus of control impacts on the risk tolerance), R14 (external locus of control impacts on the attitude towards debt), and R18 (gender impacts on the external locus of control) were not included in the integrated model because the external locus of control construct was not validated. Figure 4.3 is presented to better explain the direct, indirect, and total effects of the relationships in the integrated model, and Figure 4.4 illustrates the final integrated model with the significant relationships highlighted in blue (positive relationship) and red (negative relationship). 


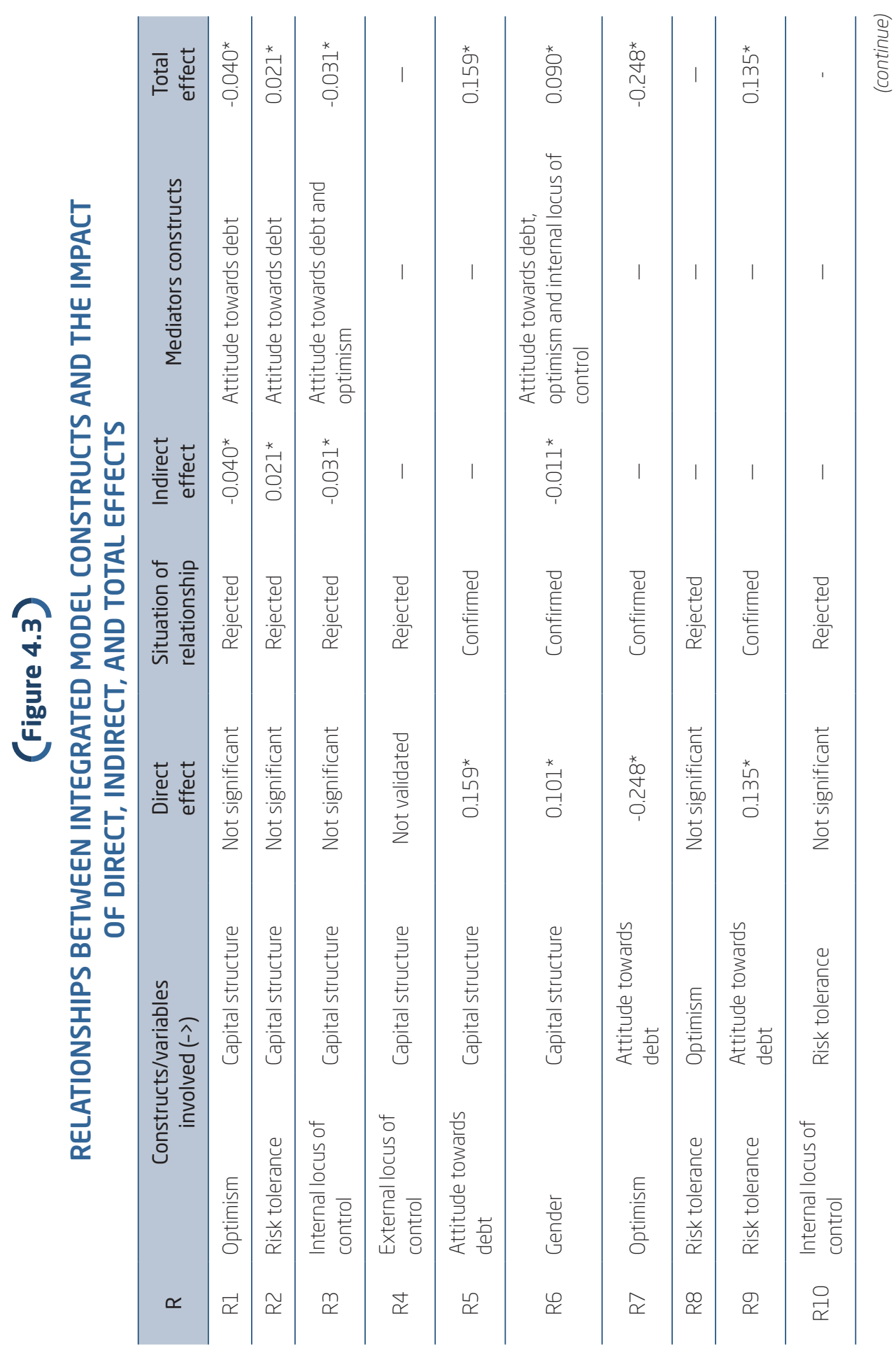




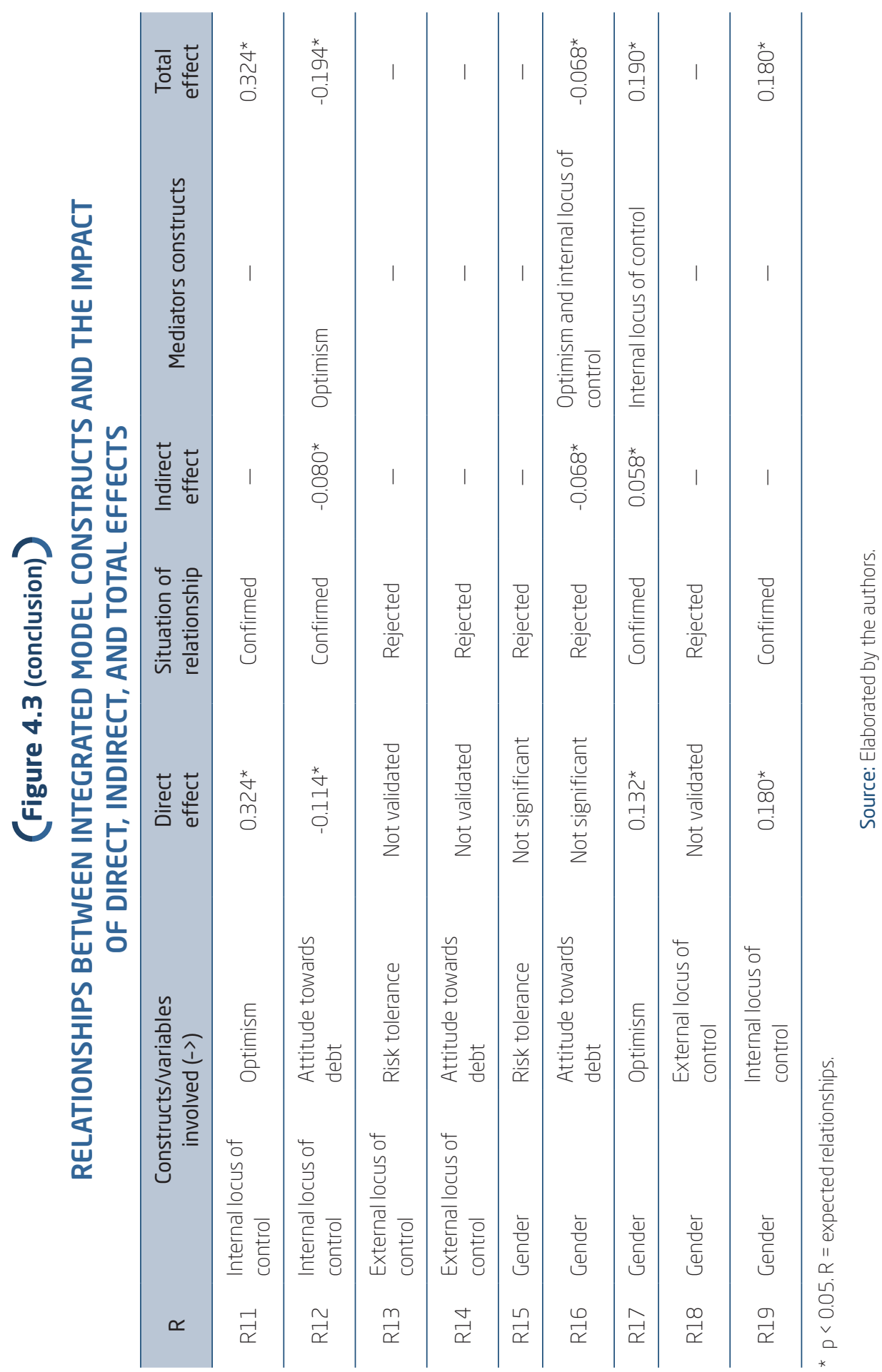


(Figure 4.4)

\section{FINAL INTEGRATED MODEL WITH SIGNIFICANT AND NON-SIGNIFICANT RELATIONSHIPS}

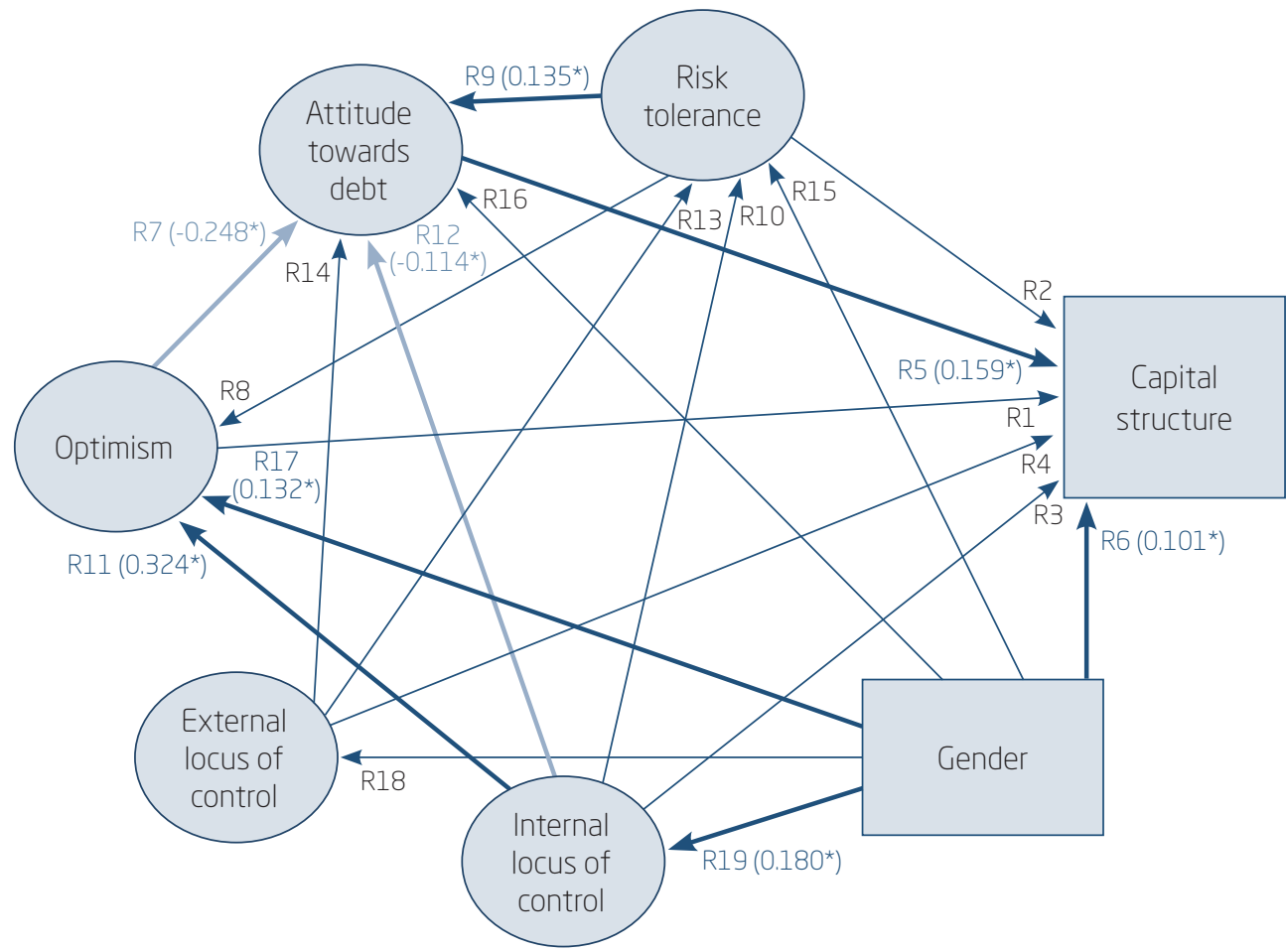

Note: Made using Amos ${ }^{\text {Tm }}$. Circles represent the constructs, squares, the variables and arrows point the established relationships. Non-significant relationships appear in navy blue (thin arrows), while significant relationships (thick arrows) are highlighted in navy blue when the effect is positive and in light blue when the effect is negative.

Source: Elaborated by the authors.

In the integrated model, 11 expected relationships were rejected, because they were not significant or not validated. Of these, seven had no significant effects, either directly or indirectly (R4, R8, R10, R13, R14, R15, and R18). However, four rejected expected relationships had indirect effects on other relationships proposed. To the expected relationship (R1), optimism had an inverse impact on capital structure (coefficient -0.040) indirectly through attitude towards debt. Risk tolerance had an indirect effect on capital structure (R2) with a positive impact of 0.021 , with attitude towards debt as mediator, while internal locus of control also presented an indirect effect on capital structure (R3), through the mediation of attitude towards debt and optimism, with a negative impact of 0.031 . 
The result for R1 is corroborated by Chaganti et al. (1996), which consulted a sample of 903 small businesses in the United States, and Hackbarth (2009), because more optimistic managers would have a higher aversion to debt, which implies a lower level of external debt. For R2, the positive effect of risk tolerance on capital structure is confirmed by Verheul and Thurik (2001) in a study of two thousand Dutch start-ups, and by Barbosa and Moraes (2003), which analyzed 43 very small Brazilian businesses, to see that a more risk-tolerant manager tends to use more debt, thus, increasing the capital structure. For R3, regarding the internal locus of control, Koropp et al. (2014), when considering a sample of 118 German family businesses, suggested that an internal sense of control is related to a lower disposition towards using debt in the capital structure and, as a consequence, to lower leverage, which is also related to optimism, as in Weinstein and Klein (1996).

Only attitude towards debt (R5) and gender (R6) presented significant direct effects on capital structure. Attitude towards debt had a positive direct impact of 0.159, while gender had a total positive impact of 0.090. Gender had a positive direct impact of 0.101 , but its total effect was lower due to the negative indirect effect $(-0.011)$ that occurred through attitude towards debt, optimism, and internal locus of control. The R5 is corroborated by Matthews et al. (1994), which analyzed a series of previous papers, and by Hoang and Otake (2014), which approached a sample of small and medium businesses in Vietnam, both arguing that a manager's attitude towards debt is aligned with the company's capital structure, that is, a higher propensity to debt would lead to a higher use of debt.

Regarding R6, although much of the literature suggests a negative relationship, as in Constantinidis et al. (2006) and Faccio et al. (2016), gender had a positive impact on capital structure, such that women managers would lead to higher leverage. This agrees with Levitan and Wieler (2008), which approached citizens in New York City, and Trindade et al. (2012), who analyzed the propensity for indebtedness among women in the southern region of Brazil, as both argued that women tend to use more debt to handle their financial commitments than men, because men tend to have more personal funds than women. It could be the case that the businesses led by women had fewer personal funds to maintain their business and thus needed to use more external debt.

From the eight proposed relationships between the personality traits (R7 to R14), four were confirmed. R7, which stated that optimism has a negative impact on attitude towards debt, was confirmed with a significant impact of -0.248, in line with Chaganti et al. (1996), in which more optimistic 
managers tend to prefer the use of internal funding rather than external. The positive impact (0.135) of risk tolerance on attitude towards debt was also confirmed in the final model (R9), corroborating studies that found an existing relationship between risk tolerance and attitude towards debt (Hutchinson, 1995; Verheul \& Thurik, 2001; Barbosa \& Moraes, 2003). Internal locus of control had total effects on optimism (R11) and attitude towards debt (R12) of 0.324 and -0.194 , respectively. These results are in accordance with Weinstein and Klein (1996), because, according to them, individuals who feel in control of their own lives tend to be more optimistic and tend to be more averse to debt (Koropp et al., 2014).

Finally, regarding the relationship between gender and profile traits, only two direct and one indirect relationship were significant. The two direct relationships found, which determined that gender affects optimism and the internal locus of control, were confirmed (R17 and R19). The impact on optimism and on the internal locus of control exhibited coefficients of 0.132 and 0.180 , respectively, showing that female managers have a higher degree of optimism and internal locus of control than male managers, supporting the results of Hinz et al. (2017), which analyzed a sample of German citizens and found that women were more optimistic than men, and of Sherman et al. (1997), which stated that women tend to present a higher internal locus of control (and they take advantage of that) than men in some life aspects. Otherwise, female managers presented a worse attitude towards debt, in an indirect way $(-0.068)$, through their optimism and internal locus of control.

\section{CONCLUDING REMARKS}

Understanding capital structure is still a major challenge. In the universe of large companies, different approaches and evidence have been presented. For small businesses, the challenge is even greater, given the peculiarities of firms and their management. The problem faced by researchers of small businesses is the lack of secondary data, because these firms are not required to publish financial and accounting statements and, in most cases, also do not have effective internal controls, which makes it difficult to identify their capital structure. Small businesses are also usually managed by a sole person, the owner or a professional, so that person's personal characteristics and preferences can affect the firm's decisions.

This research contributes to our understanding of how personality traits can influence the capital structure of micro and small businesses. The results showed that all of the analyzed traits, except for the non-validated construct 
external locus of control, exert some kind of influence on capital structure. Attitude towards debt and gender were the most significant because they had direct influences, while optimism and internal locus of control exerted a negative indirect influence, and risk tolerance had a positive indirect effect on capital structure. In addition, it was found that female managers demonstrated a higher degree of optimism and internal locus of control than male managers.

The validated relationships confirmed most of the empirical evidence presented in the literature, except for the influence of gender on capital structure. Unlike studies that found businesses managed by women are less likely to be indebted (Read, 2002; Constantinidis et al., 2006; Coleman \& Robb, 2009), in this study, businesses managed by women were more likely to be indebted. The literature indicates that, for firms in general, women have fewer of their own resources when they start a business and are less prone to raising capital from external sources (Constantinidis et al., 2006; Coleman \& Robb, 2009).

While larger firms obtain loans and financing through the banking system and financial markets, in small businesses a greater share of the indebtedness consists of resources borrowed from the entrepreneur, a partner, or relatives. In this study, these forms of indebtedness were also considered - that is, to estimate the businesses' indebtedness, the entrepreneurs were also asked to consider financial resources obtained through friends, relatives, and the use of a personal credit card. It is possible that many of the difficulties presented in the literature regarding indebtedness through traditional sources find compensation in resources obtained through other sources.

The identification of the direct influence of attitude towards debt on capital structure is even more important when there is a connection between personal and company indebtedness, as this is common in small businesses. If managers with a high degree of comfort in their attitude towards debt tend to search for more loans, the banking system can build models to evaluate the bankruptcy risks of small businesses, which may include the entrepreneur's attitude towards debt. Account managers and consultants in these institutions may include discussions about the level of personal debt in the examination of new concessions. Aid agencies for small and medium-sized businesses, particularly Brazilian service of support for micro and small enterprises (Serviço Brasileiro de Apoio às Micro e Pequenas Empresas [Sebrae]), in Brazil, must include financial management courses in their services that lead to entrepreneurs' awareness about how their attitude towards debt can influence the debts of their business. 
It should also be noted that optimism, internal locus of control, and risk tolerance affect attitude towards debt. Thus, different agents can also use these scales for the evaluation, awareness-raising, and training of their clients, because excess optimism and internal locus of control reduce the attitude to indebtedness and, consequently, can lead a business to a level of indebtedness below the ideal, while high levels of risk tolerance can make the businesses highly indebted, increasing the chance of bankruptcy.

The study faced some limitations regarding the sample and methodology. The sample does not ensure the generalizability of results - that is, only businesses in the state of Rio Grande do Sul were consulted - and could be enlarged to better develop the subject to a Brazilian or international scope. Regarding methodology, the choice of variables was based on the existing literature, so other variables not yet contemplated in the theoretical and empirical literature might exist.

Lastly, the study of the behavioral dimension in the context of business decisions has gained space with the growth of behavioral finances. However, the study of the influence of personality traits on capital structure and in other contexts in micro and small companies is still a recent area of interest. Research could advance in both, identifying other traits in the structure and understanding how those traits influence other decisions. Moreover, studies that search for a better comprehension of the role of gender in the management of micro and small businesses are promising, and a major challenge is the creation of new models capable of incorporating the manager's personality traits into the traditional theories of capital structure.

\section{MINHA EMPRESA E EU: TRAÇOS DE PERSONALIDADE DO EMPREENDEDOR E ESCOLHA DA ESTRUTURA DE CAPITAL}

\section{) RESUMO}

Objetivo: Esta pesquisa busca identificar como os traços de personalidade dos empreendedores podem influenciar a estrutura de capital das micro e pequenas empresas privadas no Brasil, que são importantes para o crescimento econômico e a subsistência de seus proprietários.

Originalidade/valor: O estudo da dimensão comportamental no contexto das decisões de negócios pode ajudar os agentes financeiros a entender 
o comportamento de seus clientes, incluindo a adoção de mecanismos que identificam possíveis decisões arriscadas ou ineficientes tomadas pelos gerentes com base em seus traços de personalidade. Também pode ajudar o governo e as instituições que apoiam micro e pequenas empresas privadas no desenvolvimento de estratégias que busquem reduzir a mortalidade dessas empresas.

Design/metodologia/abordagem: O modelo proposto envolve 19 relações esperadas que avaliam as relações entre os construtos otimismo, tolerância ao risco, senso de controle (externo e interno), atitude em relação à dívida e questões relacionadas ao gênero dos empreendedores. A amostra inclui 625 micro e pequenos empreendedores situados no estado do Rio Grande do Sul, no Brasil. A análise fatorial confirmatória e a modelagem de equações estruturais foram realizadas na análise.

Resultados: Os resultados mostraram que a atitude em relação à dívida e o gênero foram os construtos mais significativos e influenciaram diretamente a estrutura do capital, enquanto o otimismo e o lócus de controle interno exerceram influência indireta negativa, e a tolerância ao risco teve efeito indireto positivo. Além disso, gerentes do gênero feminino demonstraram maior otimismo e lócus de controle interno do que os gerentes do gênero masculino, mas tiveram uma atitude em relação à dívida pior.

\section{PALAVRAS-CHAVE}

Micro e pequenas empresas privadas. Estrutura capital. Traços de personalidade. Tomada de decisão. Finanças comportamentais.

\section{$\int$ REFERENCES}

Abdeldayem, M. M., \& Sedeek, D. S. (2018). Managerial behavior and capital structure decisions; Do overconfidence, optimism and risk aversion matter? Asian Economic and Financial Review, 8(7), 925-945. doi:10.18488/ journal.aefr.2018.87.925.945

Allport, G. W. (1937). Personality. New York: Holt.

Ang, J. S. (1992). On the theory of finance for privately held firms. Journal of Small Business Finance, 1(3), 18-203. 
Barbosa, E. G., \& Moraes, C. C. (2003). Determinants of the firm's capital structure: The case of the very small enterprises. Finance 0302001, University Library of Munich, Germany, revised 06 oct. 2003. Retrieved from https://econwpa.ub.uni-muenchen.de/econ-wp/fin/papers/0302/030 2001.pdf

Brealey, R. A., \& Myers, S.C. (2003). Principles of corporate finance. New York: McGraw-Hill.

Byrne, B. M. (2013). Structural equation modeling with AMOS: Basic concepts, applications, and programming. London: Routledge.

Carter, N., Brush, C., Greene, P., Gatewood, E., \& Hart, M. (2003). Women entrepreneurs who break through to equity financing: The influence of human, social and financial capital. Venture Capital, 5(1), 1-28. doi:10.1080/ 1369106032000082586

Chaganti, R., De Carolis, D. M., \& Deeds, D. (1996). Predictors of capital structure in small ventures. Entrepreneurship Theory and Practice, 20(2), 7-18. doi:10.1177/104225879602000202

Coleman, S., \& Robb, A. (2009). A comparison of new firm financing by gender: Evidence from the Kauffman Firm Survey data. Small Business Economics, 33(4), 397-411. doi:10.1007/s11187-009-9205-7

Constantinidis, C., Cornet, A., \& Asandei, A. (2006). Financing of womenowned ventures: The impact of gender and other owner-and firm-related variables. Venture Capital, 8(2), 133-157. doi:10.1080/13691060600572557

Cronqvist, H., Makhija, A. K., \& Yonker, S. E. (2012). Behavioral consistency in corporate finance: $\mathrm{CEO}$ personal and corporate leverage. Journal of Financial Economics, 103 (1), 20-40. doi:10.1016/j.jfineco.2011.08.005

Daskalakis, N., Jarvis, R., \& Schizas, E. (2013). Financing practices and preferences for micro and small firms. Journal of Small Business and Enterprise Development, 20(1), 80-101. doi:10.1108/14626001311298420

DataSebrae (2020). Painel de empresas: Rio Grande do Sul. Recuperado de https://datasebrae.com.br/empresas-rs/

Davies, E., \& Lea, S. E. (1995). Student attitudes to student debt. Journal of Economic Psychology, 16(4), 663-679. doi:10.1016/0167-4870(96)80014-6

Ding, C. G., Chang, K., \& Liu, N. (2009). The roles of personality and general ethical judgments in intention to not repay credit card expenses. The Service Industries Journal, 29(6), 813-834. doi:10.1080/02642060902749369

Droms, W. G., \& Strauss, S. N. (2003). Assessing risk tolerance for asset allocation. Journal of Financial Planning, 16(3), 72-77. 
Faccio, M., Marchica, M. T., \& Mura, R. (2016). CEO gender, corporate risktaking, and the efficiency of capital allocation. Journal of Corporate Finance, 39, 193-209. doi:10.1016/j.jcorpfin.2016.02.008

Gider, J., \& Hackbarth, D. (2010). Financing decisions. In H. K. Baker \& J. R. Nofsinger (Eds.), Behavioral finance: Investors, corporations, and markets. New Jersey: John Wiley \& Sons.

Hackbarth, D. (2008). Managerial traits and capital structure decisions. Journal of Financial and Quantitative Analysis, 43(4), 843-882. doi:10.1017/ S002210900001437X

Hackbarth, D. (2009). Determinants of corporate borrowing: A behavioral perspective. Journal of Corporate Finance, 15(4), 389-411. doi:10.1016/j. jcorpfin.2009.02.001

Hair, J. F., Black, W. C., Babin, B. J., \& Anderson, R. E. (2010). Multivariate Data Analysis (7th ed). Upper Saddle River: Prentice Hall.

Heaton, J. B. (2002). Managerial optimism and corporate finance. Financial Management, 31 (2), 33-45. doi:10.2307/3666221

Hinz, A., Sander, C., Glaesmer, H., Brähler, E., Zenger, M., Hilbert, A., \& Kocalevent, R. (2017). Optimism and pessimism in the general population: Psychometric properties of the Life Orientation Test (LOT-R). International Journal of Clinical and Health Psychology, 17, 161-170. doi:10.1016/j.ijchp.2017.02.003

Hoang, N. A., \& Otake, T. (2014). Credit participation and credit source selection of Vietnam small and medium enterprises. South East Asian Journal of Management, 8(2), 104-128. doi:10.21002/seam.v8i2.3929

Hurley, J. R. (1998). Agency and communion as related to "Big Five" selfrepresentations and subsequent behavior in small groups. The Journal of Psychology: Interdisciplinary and Applied, 132(3), 337-351. doi:10.1080/002 23989809599172

Hutchinson, R. W. (1995). The capital structure and investment decisions of the small owner-managed firm: Some exploratory issues. Small Business Economics, 7(3), 231-239. doi:10.1007/BF01135368

Instituto Brasileiro de Geografia e Estatística (2012). Companies demography: 2011. Rio de Janeiro: IBGE. Retrieved from https://biblioteca.ibge.gov.br/ visualizacao/livros/liv65422.pdf

Jacobs-Lawson, J. M., Waddell, E. L., \& Webb, A. K. (2011). Predictors of health locus of control in older adults. Current Psychology, 30(2), 173-183. doi:10.1007/s12144-011-9108-z 
Jacobsen, B., Lee, J. B., Marquering, W., \& Zhang, C. Y. (2014). Gender differences in optimism and asset allocation. Journal of Economic Behavior \& Organization, 107(2), 630-651. doi:10.1016/j.jebo.2014.03.007

Jensen, M. C., \& Meckling, W. H. (1976). Theory of the firm: Managerial behavior, agency costs and ownership structure. Journal of Financial Economics, 3(4), 305-360. doi:10.1016/0304-405X(76)90026-X

Kassin, S. (2003). Psychology. New Jersey: Prentice Hall.

Kluemper, D. H., Little, L. M., \& DeGroot, T. (2009). State or trait: Effects of state optimism on job-related outcomes. Journal of Organizational Behavior, 30(2), 209-231. doi:10.1002/job.591

Koropp, C., Kellermanns, F. W., Grichnik, D., \& Stanley, L. (2014). Financial decision making in family firms: An adaptation of the theory of planned behavior. Family Business Review, 27(4), 307-327. doi:10.1177/0894486 514522483

Kraus, S. J. (1995). Attitudes and the prediction of behavior: A meta-analysis of the empirical literature. Personality and Social Psychology Bulletin, 21 (1), 58-75. doi:10.1177/0146167295211007

Lea, S. E. G., Webley, P., \& Walker, C. M. (1995). Psychological factors in consumer debt: Money management, economic socialization, and credit use. Journal of Economic Psychology, 16(4), 678-701. doi:10.1016/01674870(95)00013-4

Levitan, M., \& Wieler, S. (2008). Poverty in New York City, 1969-1999: The influence of demographic change, income growth, and income inequality. Economic Policy Review, 14(1), 13-30.

Livingstone, S. M., \& Lunt, P. K. (1992). Predicting personal debt and debt repayment: Psychological, social and economic determinants. Journal of Economic Psychology, 13(1), 111-134. doi:10.1016/0167-4870(92)90055-C

Malhotra, N. K. (2011). Pesquisa de marketing: Uma orientação aplicada. Porto Alegre: Bookman.

Malmendier, U., Tate, G., \& Yan, J. (2011). Overconfidence and early-life experiences: The effect of managerial traits on corporate financial policies. The Journal of Finance, 66(5), 1687-1733. doi:10.1111/j.1540-6261.2011. 01685.x

Matthews, C. H., Vasudevan, D. P., Barton, S. L., \& Apana, R. (1994). Capital structure decision making in privately held firms: Beyond the finance paradigm. Family Business Review, 7(4), 349-367. doi:10.111/j.1741-6248. 1994.00349.x 
Matthews, G., Deary, I. J., \& Whiteman, M. C. (2009). Personality traits (3rd ed). Cambridge: Cambridge University Press.

Mendes-da-Silva, W., \& Yu, A. S. O. (2009). Sense of control empirical analysis: Understanding overconfidence. Revista de Administração Contemporânea, 13 (2), 247-271. doi:10.1590/S1415-65552009000200006

Mewse, A. J., Lea, S. E. G., \& Wrapson, W. (2010). First steps out of debt: Attitudes and social identity as predictors of contact by debtors with creditors. Journal of Economic Psychology, 31(6), 1021-1034. doi:10.1016/j. joep.2010.08.009

Mirowsky, J. (1995). Age and the sense of control. Social Psychology Quarterly, 58(1), 31-43. doi:10.2307/2787141

Mirowsky, J., \& Ross, C. E. (1991). Eliminating defense and agreement bias from measures of the sense of control: A 2 x 2 index. Social Psychology Quarterly, 54(2), 127-145. doi:10.2307/2786931

Modigliani, F., \& Miller, M. H. (1958). The cost of capital, corporation finance and the theory of investment. The American Economic Review, 48(3), 261-297.

Moura, A. G. D. (2005). Impact of the different materialism levels in the attitude towards debt and in the level of debt to financing the expenditure in low income families from the city of São Paulo. Master dissertation, Fundação Getulio Vargas, São Paulo, SP, Brasil.

Myers, S. C., \& Majluf, N. S. (1984). Corporate financing and investment decisions when firms have information that investors do not have. Journal of Financial Economics, 13(2), 187-221. doi:10.1016/0304-405X(84)90023-0

Read, L. H. (2002). The financing of small business: A comparative study of male and female small business owners. New York: Routledge.

Roszkowski, M. J., Davey, G., \& Grable, J. E. (2005). Insights from psychology and psychometrics on measuring risk tolerance. Journal of Financial Planning, 18(4), 66-77.

Scheier, M. F., Carver, C. S., \& Bridges, M. W. (1994). Distinguishing optimism from neuroticism (and trait anxiety, self-mastery, and self-esteem): A reevaluation of the Life Orientation Test. Journal of Personality and Social Psychology, 67(6), 1063-1078. doi:10.1037//0022-3514.67.6.1063

Sherman, A. C., Higgs, G. E., \& Williams, R. L. (1997). Gender differences in the locus of control construct. Psychology \& Health, 12 (2), 239-248. doi:10.1080/08870449708407402 
Stone, B., \& Maury, R. (2006). Indicators of personal financial debt using a multi-disciplinary behavioral model. Journal of Economic Psychology, 27, 543-556. doi:10.1016/j.joep.2005.11.002

Tirole, J. (2006). The theory of corporate finance. Princeton, NJ: Princeton University Press.

Tokunaga, H. (1993). The use and abuse of consumer credit: Application of psychological theory and research. Journal of Economic Psychology, 14(2), 285-316. doi:10.1016/0167-4870(93)90004-5

Trindade L. L., Righi, M. B., \& Vieira, K. M. (2012). Where does the female debt come from? Construction and validation of a PLS-PM model. Revista Eletrônica de Administração, 73(3), 718-746. doi:10.1590/S1413-231120 12000300006

Ullah, F., \& Taylor, P. (2007). Are UK technology-based small firms still finance constrained? International Entrepreneurship and Management Journal, 3(2), 189-203. doi:10.1007/s11365-006-0027-7

Verheul, I., \& Thurik, R. (2001). Start-up capital: Does gender matter? Small Business Economics, 16(4), 329-345. doi:10.1023/A:1011178629240

Waleczek, P., Zehren, T., \& Flatten, T. C. (2018). Start-up financing: How founders finance their ventures' early stage. Managerial and Decision Economics, 39(5), 535-549. doi:10.1002/mde.2925

Weinstein, N. D., \& Klein, W. M. (1996). Unrealistic optimism: Present and future. Journal of Social and Clinical Psychology, 15(1), 1-8. doi:10.1521/jscp. 1996.15.1.1

Yilmazer, T., \& Schrank, H. (2010). The use of owner resources in small and family owned businesses: Literature review and future research directions. Journal of Family and Economic Issues, 31 (4), 399-413. doi:10.1007/s10834010-9224-1

Yousuf, S. (1997). Financing small businesses: A comparative study of Pakistaniimmigrant businesses and UK-indigenous businesses in the travel trade. Doctoral thesis, Cranfield University, Cranfield, United Kingdom. 


\section{AUTHOR NOTES}

Kelmara M. Vieira, Ph.D by the Postgraduate Program in Administration, Federal University of Rio Grande do Sul (UFRGS); Vanessa M. Valcanover, master by the Postgraduate Program in Administration, Federal University of Santa Maria (UFSM); Ani C. G. Potrich, Ph.D by the Postgraduate Program in Administration, Federal University of Santa Maria (UFSM); Everton A. Cavalheiro, Ph.D by the Postgraduate Program in Administration, Federal University of Santa Maria (UFSM).

Kelmara M. Vieira is now associate professor at the Center for Social and Human Sciences of the Federal University of Santa Maria (UFSM); Vanessa M. Valcanover is now PhD student at the Postgraduate Program in Administration of the Federal University of Santa Catarina (UFSC); Ani C. G. Potrich is now professor at the Postgraduate Program in Administration of the Federal University of Santa Catarina (UFSC); Everton A. Cavalheiro is now professor at the Engineering Center of the Federal University of Pelotas (UFPEL).

Correspondence concerning this article should be addressed to Vanessa M. Valcanover, Universidade Federal de Santa Catarina (UFSC), Campus Reitor João David Ferreira Lima, s/n, Trindade, Florianópolis, Santa Catarina, Brasil, CEP 88040-900.

E-mail: vanessamvalcanover@gmail.com 


\section{(APPENDIX)}

\section{Questionnaire}

Q1. Gender: 1.1 ( ) male 1.2 ( ) female

Q2. Age: years

Q3. Marital status:

3.1 ( ) married

3.2 ( ) single

3.3 ( ) divorced

3.4 ( ) stable union

3.5 ( ) widow/widower

Q4. Schooling:
4.1 ( ) Elementary School
4.2 ( ) High School
4.3 ( ) Graduation
4.4 ( ) Postgraduation

\section{SCALES}

Risk tolerance ( 1 - strongly disagree; 2 - disagree; 3 - neutral; 4 - agree; 5 - completely agree)

Questions from Droms and Strauss (2003)

Q5. Earning a high long-term total return that will allow

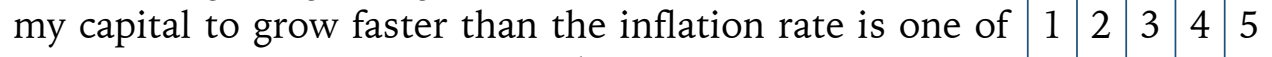
my most important investment objectives. ${ }^{*}$

Q6. I would like an investment that provides me with an opportunity to defer taxation of capital gains and/or interest to future years.

Q7. I do not require a high level of current income from my investments.

Q8. I am willing to tolerate sharp up and down swings in the return on my investments in order to seek a potentially higher return than would normally be expected from more stable investments.*

Q9. I am willing to risk a short-term loss in return for a potentially higher long-run rate of return.*

Q10. I am financially able to accept a low level of liquidity in my investment portfolio.*

* Validated questions. 
Optimism (1 - strongly disagree; 2 - disagree; 3 - neutral; 4 - agree; 5 - completely agree)

Questions from Scheier, Carver and Bridges (1994)

\begin{tabular}{|l|l|l|l|l|l|}
\hline Q11. In uncertain times, I usually expect the best.* & 1 & 2 & 3 & 4 & 5 \\
\hline Q12. It's easy for me to relax. & 1 & 2 & 3 & 4 & 5 \\
\hline Q13. If something can go wrong for me, it will.* & 1 & 2 & 3 & 4 & 5 \\
\hline Q14. I'm always optimistic about my future.* & 1 & 2 & 3 & 4 & 5 \\
\hline Q15. I enjoy my friends a lot. & 1 & 2 & 3 & 4 & 5 \\
\hline Q16. It's important for me to keep busy. & 1 & 2 & 3 & 4 & 5 \\
\hline Q17. I hardly ever expect things to go my way.* & 1 & 2 & 3 & 4 & 5 \\
\hline Q18. I don't get upset too easily. & 1 & 2 & 3 & 4 & 5 \\
\hline Q19. I rarely count on good things happening to me.* & 1 & 2 & 3 & 4 & 5 \\
\hline $\begin{array}{l}\text { Q20. Overall, I expect more good things to happen than } \\
\text { bad.* }\end{array}$ & 1 & 2 & 3 & 4 & 5 \\
\hline
\end{tabular}

* Validated questions.

Internal locus of control ( 1 - strongly disagree; 2 - disagree; 3 - neutral; 4 - agree; 5 - completely agree)

Questions from Mirowsky and Ross (1991)

\begin{tabular}{|l|l|l|l|l|l|}
\hline Q21. I am responsible for my own success.* & 1 & 2 & 3 & 4 & 5 \\
\hline $\begin{array}{l}\text { Q22. I can do just about anything, if I really set my mind } \\
\text { to it.* }\end{array}$ & 1 & 2 & 3 & 4 & 5 \\
\hline Q23. My misfortunes are the result of mistakes I have made.* $^{*}$ & 1 & 2 & 3 & 4 & 5 \\
\hline Q24. I am responsible for my failures. $^{*}$ & 1 & 2 & 3 & 4 & 5 \\
\hline
\end{tabular}

* Validated questions. 
External locus of control (1 - strongly disagree; 2 - disagree; 3 - neutral; 4 - agree; 5 - completely agree)

Questions from Mirowsky and Ross (1991)

\begin{tabular}{|c|c|c|c|c|}
\hline $\begin{array}{l}\text { Q25. The really good things that happen to me are mostly } \\
\text { luck. }\end{array}$ & 1 & 2 & 3 & 4 \\
\hline $\begin{array}{l}\text { Q26. There's no sense planning a lot - if something good is } \\
\text { supposed to happen, it will. }\end{array}$ & 1 & 2 & 3 & 4 \\
\hline Q27. Most of my problems are due to bad breaks. & 1 & 2 & 3 & 4 \\
\hline $\begin{array}{l}\text { Q28. I have little control over the bad things that happen } \\
\text { to me. }\end{array}$ & 1 & 2 & 3 & 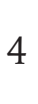 \\
\hline
\end{tabular}

Attitude towards debt ( 1 - strongly disagree; 2 - disagree; 3 - neutral; 4 - agree; 5 - completely agree)

Translated questions from Moura (2005)

\begin{tabular}{|l|l|l|l|l|l|}
\hline $\begin{array}{l}\text { Q29. I think it's normal for people to be indebted to pay } \\
\text { for things.* }\end{array}$ & 1 & 2 & 3 & 4 & 5 \\
\hline $\begin{array}{l}\text { Q30. It's important to know how to control the expenses } \\
\text { of my home. }\end{array}$ & 1 & 2 & 3 & 4 & 5 \\
\hline $\begin{array}{l}\text { Q31. I know exactly how much I owe to stores, credit card } \\
\text { or banks. }\end{array}$ & 1 & 2 & 3 & 4 & 5 \\
\hline $\begin{array}{l}\text { Q32. It's better to save money first, and only then, to } \\
\text { spend it.* }\end{array}$ & 1 & 2 & 3 & 4 & 5 \\
\hline $\begin{array}{l}\text { Q33. I prefer to pay in installments than to wait until I have } \\
\text { money to pay in cash.* }\end{array}$ & 1 & 2 & 3 & 4 & 5 \\
\hline $\begin{array}{l}\text { Q34. I prefer to pay in installments even if it is more } \\
\text { expensive in total.* }\end{array}$ & 1 & 2 & 3 & 4 & 5 \\
\hline $\begin{array}{l}\text { Q35. People would be disappointed with me if they knew } \\
\text { I have debts. }\end{array}$ & 1 & 2 & 3 & 4 & 5 \\
\hline Q36. It's not right to spend more than the amount I earn. & 1 & 2 & 3 & 4 & 5 \\
\hline Q37. Having debt is not a problem if I know I can afford it. & 1 & 2 & 3 & 4 & 5 \\
\hline
\end{tabular}

* Validated questions. 
Q38. When did your business start? (year)

Q39. What is the sector of your business? 39.1 ( ) retail 39.2 ( ) services 39.3 ( ) industry 39.4() construction

Q40. Do you consider your business a family business? 40.1 ( ) yes 40.2 ( ) no

Q41. How many family members work in your business? 41.1 ( ) none 41.2 ( ) one 41.3 ( ) two 41.4 ( ) three 41.5 ( ) four 41.6 ( ) more than four

Q42. Do you face difficulties in obtaining external funding for the growth/ expansion of your company?

42.1( ) yes 40.2 ( ) no

Q43. What is the value of the assets (inventories, machines, land, buildings, receivables etc.) of your company today?

\begin{tabular}{|c|c|c|c|}
\hline Below BRL 10,000.00 & {$[\quad]$} & $\begin{array}{l}\text { Between BRL 100,000.00 and } \\
\text { BRL 110,000.00 }\end{array}$ & {$[\quad]$} \\
\hline $\begin{array}{l}\text { Between BRL 10,000.00 and } \\
\text { BRL 20,000.00 }\end{array}$ & {$[\quad]$} & $\begin{array}{l}\text { Between BRL 110,000.00 and } \\
\text { BRL 120,000.00 }\end{array}$ & {$[\quad]$} \\
\hline $\begin{array}{l}\text { Between BRL 20,000.00 and } \\
\text { BRL 30,000.00 }\end{array}$ & {$[\quad]$} & $\begin{array}{l}\text { Between BRL } 120,000.00 \text { and } \\
\text { BRL 130,000.00 }\end{array}$ & {$[\quad]$} \\
\hline $\begin{array}{l}\text { Between BRL 30,000.00 and } \\
\text { BRL 40,000.00 }\end{array}$ & {$[\quad]$} & $\begin{array}{l}\text { Between BRL 130,000.00 and } \\
\text { BRL 140,000.00 }\end{array}$ & [ ] \\
\hline $\begin{array}{l}\text { Between BRL } 40,000.00 \text { and } \\
\text { BRL 50,000.00 }\end{array}$ & {$[\quad]$} & $\begin{array}{l}\text { Between BRL 140,000.00 and } \\
\text { BRL 150,000.00 }\end{array}$ & {$[\quad]$} \\
\hline $\begin{array}{l}\text { Between BRL 50,000.00 and } \\
\text { BRL 60,000.00 }\end{array}$ & {$[\quad]$} & $\begin{array}{l}\text { Between BRL 150,000.00 and } \\
\text { BRL 160,000.00 }\end{array}$ & {$[\quad]$} \\
\hline $\begin{array}{l}\text { Between BRL } 60,000.00 \text { and } \\
\text { BRL 70,000.00 }\end{array}$ & {$[\quad]$} & $\begin{array}{l}\text { Between BRL 160,000.00 and } \\
\text { BRL 170,000.00 }\end{array}$ & {$[$ ] } \\
\hline $\begin{array}{l}\text { Between BRL } 70,000.00 \text { and } \\
\text { BRL } 80,000.00\end{array}$ & {$[\quad]$} & $\begin{array}{l}\text { Between BRL 170,000.00 and } \\
\text { BRL 180,000.00 }\end{array}$ & {$[\quad]$} \\
\hline $\begin{array}{l}\text { Between BRL } 80,000.00 \text { and } \\
\text { BRL } 90,000.00\end{array}$ & {$[\quad]$} & $\begin{array}{l}\text { Between BRL 180,000.00 and } \\
\text { BRL 190,000.00 }\end{array}$ & {$[\quad]$} \\
\hline $\begin{array}{l}\text { Between BRL } 90,000.00 \text { and } \\
\text { BRL 100,000.00 }\end{array}$ & {$[\quad]$} & $\begin{array}{l}\text { Between BRL 190,000.00 and } \\
\text { BRL 200,000.00 }\end{array}$ & {$[\quad]$} \\
\hline Above BRL 200,000.00. Hov & {$[\quad]$} & & \\
\hline
\end{tabular}


Q44. How much debt (banks, friends, relatives, salaries, personal credit card, company's credit card etc.) does your company has today?

\begin{tabular}{|c|c|c|c|c|}
\hline Below BRL 5,000 & [ ] & $\begin{array}{l}\text { Between BRL 5,000 } \\
\text { and BRL 15,000 }\end{array}$ & [ ] & $\begin{array}{l}\text { Between BRL 15,000 } \\
\text { and BRL 25,000 }\end{array}$ \\
\hline $\begin{array}{l}\text { Between BRL 25,000 } \\
\text { and BRL 35,000 }\end{array}$ & [ ] & $\begin{array}{l}\text { Between BRL 35,000 } \\
\text { and BRL 45,000 }\end{array}$ & [ ] & $\begin{array}{l}\text { Between BRL } 45,000 \\
\text { and BRL 55,000 }\end{array}$ \\
\hline $\begin{array}{l}\text { Between BRL 55,000 } \\
\text { and BRL 65,000 }\end{array}$ & [ ] & $\begin{array}{l}\text { Between BRL 65,000 } \\
\text { and BRL 75,000 }\end{array}$ & [ ] & $\begin{array}{l}\text { Between BRL 75,000 } \\
\text { and BRL 85,000 }\end{array}$ \\
\hline $\begin{array}{l}\text { Between BRL 85,000 } \\
\text { and BRL 95,000 }\end{array}$ & [ ] & $\begin{array}{l}\text { Between BRL 95,000 } \\
\text { and BRL 105,000 }\end{array}$ & [ ] & $\begin{array}{l}\text { Between BRL 105,000 [ ] } \\
\text { and BRL 115,000 }\end{array}$ \\
\hline $\begin{array}{l}\text { Between BRL 115,000 } \\
\text { and BRL 125,000 }\end{array}$ & [ ] & $\begin{array}{l}\text { Between BRL 125,000 } \\
\text { and BRL 135,000 }\end{array}$ & [ ] & $\begin{array}{l}\text { Between BRL 135,000 [ ] } \\
\text { and BRL 145,000 }\end{array}$ \\
\hline $\begin{array}{l}\text { Between BRL 145,000 } \\
\text { and BRL 155,000 }\end{array}$ & [ ] & $\begin{array}{l}\text { Between BRL 155,000 } \\
\text { and BRL 165,000 }\end{array}$ & [ ] & $\begin{array}{l}\text { Between BRL 165,000 [ ] } \\
\text { and BRL 175,000 }\end{array}$ \\
\hline $\begin{array}{l}\text { Between BRL } 175,000 \\
\text { and BRL } 185,000\end{array}$ & [ ] & $\begin{array}{l}\text { Between BRL 185,000 } \\
\text { and BRL 195,000 }\end{array}$ & [ ] & $\begin{array}{l}\text { Above BRL } 195,000 . \\
\text { How much? }\end{array}$ \\
\hline
\end{tabular}

Q45. How would you describe your company's relationship with banks? 45.1 ( ) great 45.2 ( ) good 45.3 ( ) indifferent 45.4 ( ) bad 45.5 ( ) terrible

EDITORIAL BOARD

Editor-in-chief

Gilberto Perez

Associated Editor

Eduardo Kazuo Kayo

Technical Support

Vitória Batista Santos Silva

\section{EDITORIAL PRODUCTION}

Publishing Coordination

Jéssica Dametta

Layout Designer

Editorial Intern

Paula Di Sessa Vavlis

Graphic Designer

Libro
Language Editor

Daniel de Almeida Leão 